\title{
ENRICHING LEARNING EXPERIENCE THROUGH MULTIDISCIPLINARY DESIGN EDUCATION: STRUCTURE PROPOSAL FOR A LANDSCAPE DESIGN COURSE
}

\author{
İpek KAŞTAŞ UZUN \\ İzmir University of Economics, Turkey \\ ipek.kastas@ieu.edu.tr \\ https://orcid.org/0000-0002-1211-1766
}

\begin{abstract}
Design related fields are quite intricate and it is hard to define strict boundaries in between these disciplines which cause the necessity of collaboration. Especially during professional careers, designers work in multidisciplinary environments where they need to develop responses collaboratively. However, undergraduate design education is being criticized for missing to fulfill this need. The aim of this paper is to discuss the role and benefits of multidisciplinary design education with the example of the course named "An Introduction to Contemporary Architectural Landscaping". As the methodology of the paper, through deconstruction of the 3 parted course structure and analysis of student works, this paper analyses the role of a multidisciplinary education on students' learning experiences. First two parts of the course focus on technical aspects of landscape architecture discipline, and cultural, physiological and psychological effects of landscape projects for users. Last part of the course focus on creating a platform for students to work in collaboration with other students to gain practical experience in design field where they develop a landscape architecture project on sites from their near environments. There are three main findings of the study. Firstly, inclusion of students from different disciplines in the same course increases the success rate via cross-learning experiences. Secondly, during design education, having the chance of participation to courses from different disciplines help to broaden students' perspectives on problem solving during design phase. Finally, projects in environments that students experience in their everyday life increase their success rates. Results of the study that is based on the outcomes of the course that is conducted with the students of two different design departments indicate that this course structure and projects that are designed can be a guide for other design courses to develop a multidisciplinary course structure to include students from different disciplines, enrich their learning experiences and success after graduation.
\end{abstract}

\section{ÖĞRENME DENEYIMININ ÇOK DİSIPLINLI TASARIM EĞITIMİ ILE GELIŞTIRILLMESI: BİR PEYZAJ TASARIMI DERSİ STRÜKTÜR ÖNERISİ}

\section{$\ddot{\mathbf{O Z Z}}$}

Tasarım disiplinleri arasında net sınırlar çizmek bu disiplinler arasındaki bağların sıkıllğı ve aynı zamanda geçirgenliği nedeni ile çok zordur. Dolayısıyla bu disiplinler arasında iş birliği yapmak kaçınılmazdır. Tasarımcılar özellikle meslek hayatları boyunca çok disiplinli ortamlarda çalışarak tasarım problemlerine diğer disiplinlerle ortak cevaplar vermek zorunda kalmaktadırlar. Ancak tasarım eğitimin yapısı incelendiğinde, tasarımcıların profesyonel hayatta sıklıkla ihtiyaç duydukları çok disiplinli yaklaşımın üzerinde çok durulmadığ 1 görülmektedir. Bu makalenin amacı "Çağdaş Peyzaj Tasarımına Giriş" dersi örneğinde çok disiplinli tasarım eğitimi yaklaşımlarının tasarımdaki rolü ve faydalarını incelemektir. Temel metot olarak bu makale söz konusu dersin üç aşamadan oluşan yapısını ve derste üretilen projeleri inceleyerek, çok disiplinli tasarım eğitiminin öğrencilerin öğrenme deneyimlerine nasıl katkı koyduğunu araştırır. Dersin ilk iki kısmı peyzaj tasarımı disiplininin teknik konularına ve peyzaj tasarımının kullanıcıların üzerindeki kültürel, fizyolojik ve psikolojik etkilerine odaklanırken, dersin son kısmı farklı disiplinlerden gelen öğrencilerin kendi yakın çevrelerindeki ekolojik açıdan problemli buldukları bir alanda yapacakları bir peyzaj tasarımı projesine zemin 
hazırlamaktadır. Bu çalışmanın üç temel sonucu vardır. Birincisi, farklı tasarım disiplinlerinden gelen öğrencilerin aynı dersi birlikte almaları çapraz öğrenme deneyimleri sayesinde başarı düzeylerini arttırmaktadır. İkinci olarak, çalışma öğrencilerin eğitim hayatları boyunca kendi alanları dışında farklı disiplinlerden dersler almalarının problem çözme ve tasarım becerilerini geliştirdiğini göstermektedir. Son olarak da öğrencilerin kendi yakın çevrelerindeki problemli alanlarda çalışmaları, projeye olan ilgilerini arttırarak daha başarılı oldukları görülmüştür. Araştırma sonuçlarından yola çıkarak bu dersin çok disiplinli yapısı ve derste geliştirilen projelerin içerikleri diğer tasarım derslerinin oluşturulmasında, farklı tasarım alanlarından öğrencilerin bir arada öğrenme deneyimini yaşamalarına olanak sağlayan bir zemin oluşturarak öğrencilerin mezuniyet sonrası başarılarının arttırılmasında bir örnek ve yol gösterici olabileceği düşünülmektedir.

\section{Anahtar Kelimeler: Çok Disiplinli Öğretim, Peyzaj Tasarımı, Tasarım Ĕ̈itimi, Ders Yapısı Tasarımı}

\section{INTRODUCTION}

There are fluid boundaries in between art and design related fields such as architecture, landscape architecture or interior architecture. These fields are quite intricate and it is hard to define strict boundaries in between these disciplines especially in professional practice where designers should work collaboratively to answer the needs of increasingly complex necessities of the world in 21st century in order to succeed. Design education should also highlight the importance of such multidisciplinary collaborations and raise students who can be successful in their professional design career. Deriving from this necessity, certain design schools started to shape their curriculums accordingly - one of which is Izmir University of Economics, Faculty of Fine Arts and Design. With the awareness on the importance of multidisciplinary design education, the curriculum of five design disciplines Architecture (ARCH), Interior Architecture and Environmental Design (IAED), Industrial Design (ID), Visual Communication and Design (VCD), Fashion and Textile Design (FA) - are designed in İzmir University of Economics, Faculty of Fine Arts and Design (FFAD). According to the structure of FFAD, while students of each department take courses from their core disciplines and learn the main theories and principles of their professions, they also corporate with students from other design disciplines during elective and supportive courses during their four years of design education.

"An Introduction to Contemporary Architectural Landscaping" course which is one of the elective courses from the curriculum of FFAD, is structured with an emphasis on the importance of multidisciplinary design education. This course is open to junior and senior year students of IAED and ARCH Departments. This paper specifically and solely focuses on the structure of this course and experiences of the students of two departments to discuss how a design course can be structured by taking into consideration of the needs of different design disciplines and how existence of students from different disciplines in the same class environment can enrich the learning experience of students. In order to do so, the scope of this paper firstly includes the discussions in the literature regarding the necessity and importance of multidisciplinary approach in design education. Following the theoretical discussions, the structure of the course and how this structure enriches students' learning experiences is explained. In the last part, the paper highlights three important outcomes that are acquired during last seven years that this course is being thought.

\section{ROLE OF MULTIDISCIPLINARY COLLOBORATION IN DESIGN}

In today's world, where digitalization and globalization are increasingly dominating professional practices and as a result of the "two momentum trends of this century which are growing complexity and increasing rates of change" (Barnes-Powell, 2008: 378), it is inevitable to formulate responses collaboratively with multiple and diverse disciplines (Fleischmann, 2013). Designers now also need to be able to answer the needs of changing economic, social, cultural and technological aspects and design based solutions became more vital and complicated. To be successful in this challenging environment, it is required to collaborate with professionals from other disciplines who can contribute to the team with varying knowledge, vocabularies, working methods, and thinking (Kimmons and Spruiell, 2005). Friedman (2000) also highlights the importance of collaborative work as this situation is not easy for designers to work in this 'complex, changing professional environment since design involves more skills 
and knowledge than one designer can hope to provide' (Friedman, 2000: 21). Consequently, it is possible to state that 'boundaries between design disciplines are more fluid' today (Icograda, 2011).

The ability of problem solving is also crucial in design profession and problem solving often includes a multitude of other disciplines (Whyte and Bessant, 2007; Dubberly, 2011; Hunt, 2011) and skills of designers should not only be focused on their own disciplines but provide solutions as a part of larger systems that are effective for 'a group of interacting, interrelated, and interdependent components that form a complex and unified whole' (Pegasus Communications, 2012) and thus resulting in the growth of interdisciplinary knowledge. In the professional design world, while working on architectural design projects intersection of multiple disciplines and cooperation among the professionals from multiple disciplines are very common. During the design and construction phases of a project, professionals from various disciplines come together to develop the site, the building's structure, and the building's interior and exterior components. Among these disciplines we can usually see the coordination of professionals from different engineering disciplines, architecture, urban planning, construction, interior design, and landscape architecture. Existence of participants from multiple disciplines during all design phases can help to avoid redesigns and unplanned modifications, which enables a more sustainable and reasonable plan for the construction phase (Sebastian, 2010).

The increasing complexity of the construction industry and role of multidisciplinary work in the real life projects has revealed the importance of the awareness of such a need and the necessity to educate students with a "clearer understanding of the collaborative environment in which they will work" (IIDA Report, 1998: 54). Bender (2005) states that educating students in a multidisciplinary environment help them to be more prepared to collaborations with other design disciplines in their professional life. According to Kimmons and Spruiell (2005) it is required for students to be able to understand and resolve problems, work in collaboration with students from other disciplines, and have a solid knowledge of both their own and related professions (Kimmons and Spruiell, 2005). However, research indicates that employers often criticize new graduates as they lack skills of problem solving in multidisciplinary environments. In professional arena, one of the first criteria that employers are seeking is employees who are good at problem solving, working collaboratively, and show enthusiasm for their jobs (Blossom, Matthews, \& Gibson, 2002).

\section{ROLE OF EDUCATION IN ENHANCING MULTIDISCIPLANARY DESIGN APPROACHES}

Due to the inherent multidisciplinary structure of the design profession, its education should also provoke collaboration and teamwork (Pektaş, 2007). In design education, multidisciplinary collaboration is inevitable result of changing and developing knowledge areas and aims to give students a thinking approach that works in multiple layers. Such an approach is beneficial for students to improve their design skills, self-confidence and empowers communication between different design disciplines (Masters, Baker and Jodon, 2013).

It is utmost important for design education to provide necessary experience by creating chances for students to participate in multidisciplinary collaborative processes to make sure that graduating students can success in the challenging work environment. It is surprising to see that although multidisciplinary approach in the professional design world is inevitable and as working structures in the design profession have changed from a solitary approach to working as part of collaborative and multidisciplinary teams, this important strategy is not reflected to the curriculum of most of the design schools (Soliman, 2017). Especially in undergraduate level, such multidisciplinary approaches in design education are rare. Design educators are commonly criticized by being ignorant to the working processes of today's designers and what design students need to be prepared for (Haukka, S. 2010; Canniffe, 2011). According to Fleischmann (2013), while collaboration and interaction with other disciplines is increasingly articulated as a key skill for a designer in today's design world educating such a designer with such a perspective is less paid attention.

Deriving from these criticisms, there is an increasing debate regarding the need for a change in the design education (Icograda, 2011), as it is criticized being stuck in the past (Davis, 2011) and cannot 
keep up with the needs of the demands of the changed scope of the profession and the marketplace (Fleischmann, 2013).

Although, there is a strong argument regarding the lack of modernization of design education by integrating a multidisciplinary approach, research also indicates that even though it is not that fast, the process of re-thinking design education has begun (Szenasy, 2004). As a result of surveys realized among North American and Australian design educators, it is found that educators realize the importance of interdisciplinary collaboration for students and they plan to implement improvements (Victoria, 2009).

According to Yurtsever and Çakır's research (2012), architectural education in Turkey is mostly based on solitary disciplinary instruction. Although there is a constant discussion of integrating interdisciplinary education to their curriculums, this intention cannot go further than being an intention and in practical there are not many examples that can pursue this aim. Erkan (2013) also state that, as she analyzed all interior architecture and industrial design school programs in Turkey, only $18 \%$ of the courses in Interior Architecture and 14\% of Industrial Product Design programs can be considered open to multidisciplinary collaborations.

One of the schools that realize the need for a collaborative and multidisciplinary design education is Izmir University of Economics and the next part of the paper explains the core structure of design education in Faculty of Fine Arts and Design in one of the leading foundation universities in Turkey.

\section{STRUCTURING A MULTIDISCIPLINEAR LANDSCAPE DESIGN COURSE}

Realizing the need for a multidisciplinary approach in the contemporary design education, the overall structure of the curriculums of the five departments - Architecture (ARCH), Interior Architecture and Environmental Design (IAED), Industrial Design (ID), Visual Communication and Design (VCD), Fashion and Textile Design (FA) - are designed in İzmir University of Economics, Faculty of Fine Arts and Design. Students of each department start their education all together and they take $85 \%$ to $92 \%$ (depending on departments) of their courses such as Art and Design Studio, Drawing and Representation, and History of Art and Design together in their freshman year. As the departments continue their curriculums separately after the first year, they start to specialize in their own fields with courses such as Architectural Construction and Materials and Building Construction Project for Arch students or Environmental Control Systems for IAED and Interior Architecture Studio for IAED students. Along with these department specific courses multidisciplinary approach continues during the rest of the education with courses that students from different departments take together. These courses include both obligatory courses such as Furniture Design for students of IAED and ID, Drawing and Visualization courses for ARCH, IAED and ID students and elective courses such as Textile Design for IAED and FA students and Spatial Photography course for all departments' students. In addition to the curriculum design, the design of the faculty building aims to support this multidisciplinary structure. Each floor in the building is reserved to students of different years such as 4 th floor is for freshmen, 3 rd for sophomore, 2 nd for junior and 1 st for senior year students. With this structure, the contact and coordination among students of different departments is achieved and students find the chance to follow what students of other departments are working on.

One of the selection criteria of faculty members of the departments also underlines this structure. For instance, there are architects, interior architects, landscape architects, artists and furniture designers teaching in IAED. By being a landscape architect and urban designer, teaching in the Department of Interior Architecture and Environmental Design, and being a part of such a diverse and multidisciplinary structure, I structured "An Introduction to Contemporary Architectural Landscaping" elective course as one of the courses that can be taken by students of different departments at the same time. Focusing on the basic knowledge and theories of landscape design for junior and senior IAED and ARCH students, the educational structure of this course is also multidisciplinary and divided into three main parts.

To discuss how a design course can be structured by taking into consideration of the needs of different design disciplines and how presence of students from different disciplines in the same class environment 
can enrich the learning experience of students, the methodology of this study is based on the deconstruction and explanation of the course structure which is mainly composed of three parts: Technical aspects of landscape design; cultural, physiological and psychological effects of landscape design, and landscape project development process of students. Through the analysis of the content of the first two parts of the course, the role of a multidisciplinary content in a design course and how this content can be enriched according to the needs of students who are not familiar to the topic is discussed. Third part of the course is based on the analysis of student project development processes and how different phases of a landscape design project can be developed in the class environment together with the inputs of all students from two different departments can enhance students' learning experiences is analyzed.

First part of the course is mainly an introduction to the basic concepts, structure and the technical aspects of the landscape architecture discipline and aims to teach students who are coming from different design disciplines, concepts that they are not very familiar such as hard and soft landscape materials, main stages of a landscape design project, the basic principles of planting design including how to design and define a space using landscape elements, indigenous garden design and presentation techniques (see Picture 1).

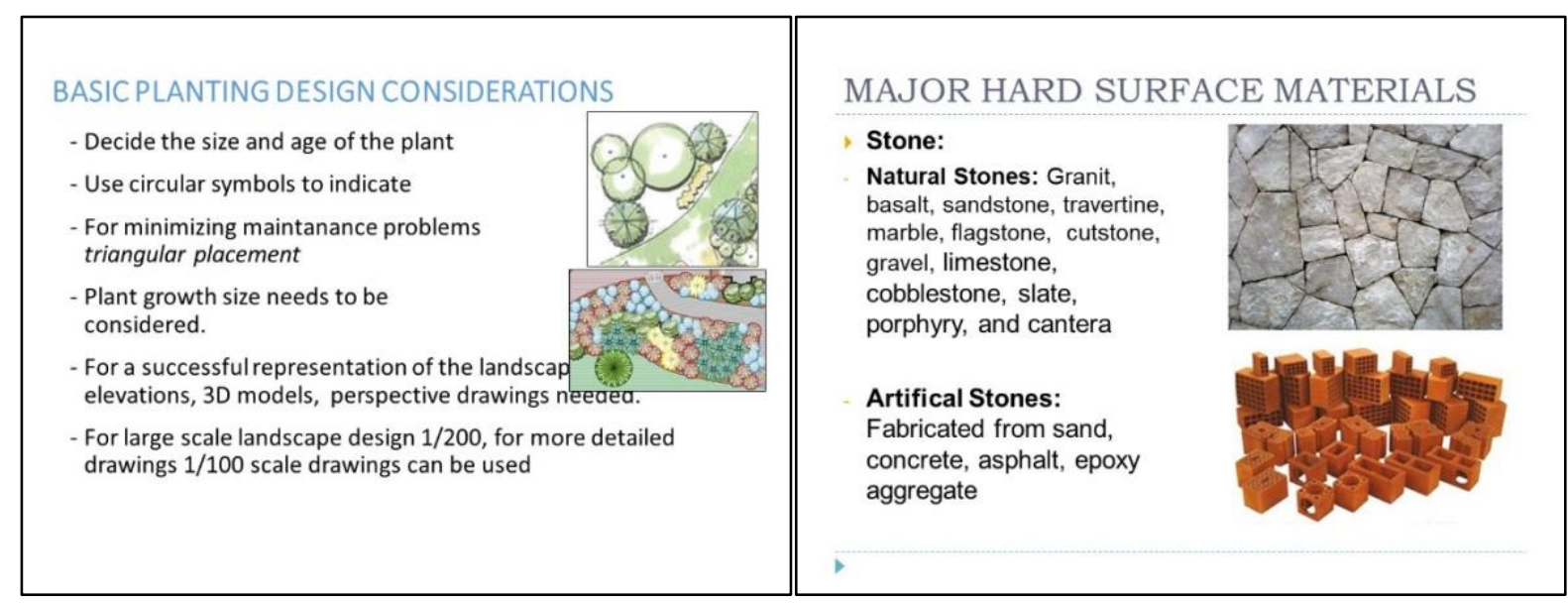

Picture 1. Lecture slide examples for technical aspects of landscape design (Author's lecture notes).

The second part of the course is mainly based on the cultural, physiological and psychological effects of the discipline and specifically highlights that living content (plants) of the landscape design projects have important impacts on the users and how they can be used as a design element is different than the non-living materials of interior architecture and architecture disciplines. This part mainly aims to raise an awareness of landscape design's roles ranging from policy making to resolve problematic issues for the future of the earth to the improving the psychology of users through enriching the quality of their living environments. This part focuses on topics ranging from the history of landscape design to the sensual and psychological effects of landscape elements, from the role of climate sensitive design for sustainability to ecological restoration (see Picture 2). 


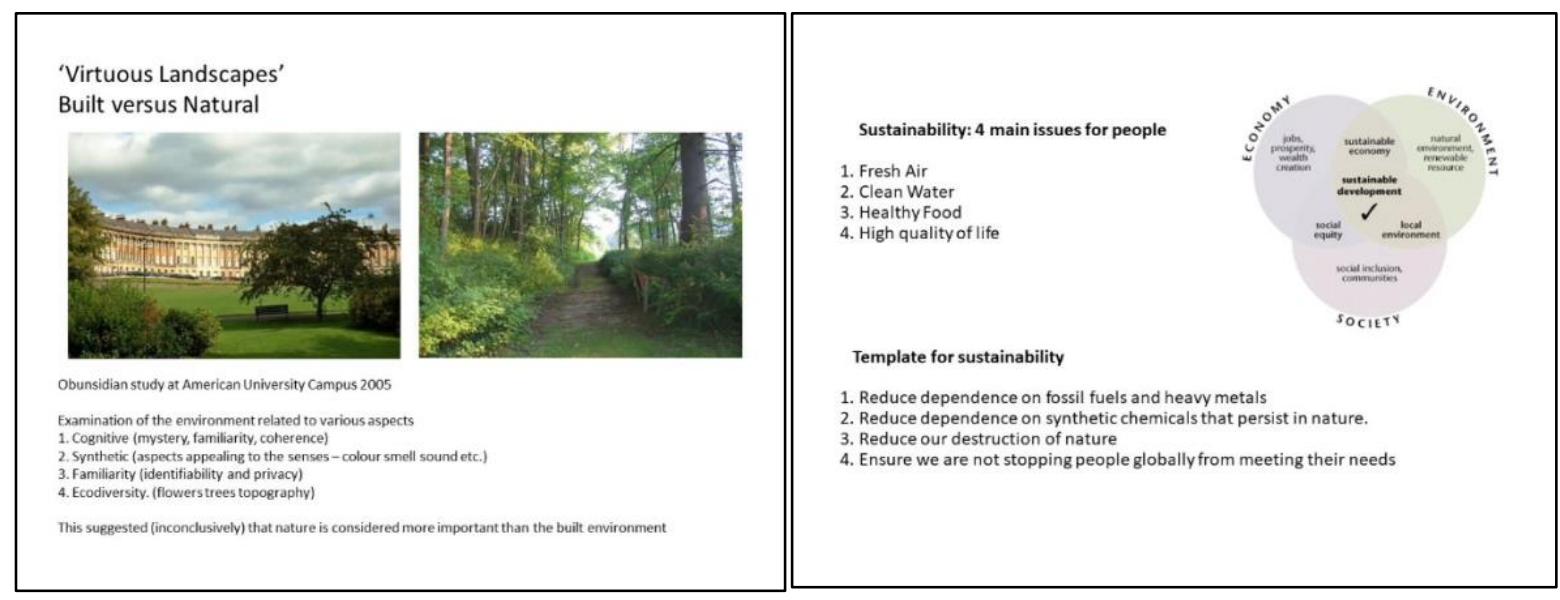

Picture 2. Lecture slide examples for cultural, physiological and psychological effects of landscape design (Author's lecture notes).

Finally, the last part of the course expects students to use the information acquired from the first and second part of this course and combine it with their prior design education in their core design disciplines to develop a landscape architecture project on selected project sites from students' near environments (see Figure 1). The need for a previous design knowledge base creates the necessity of more experienced students who are good at problem solving and familiar to different steps of a design project, from site analysis to concept development, from design development to drawing construction details. That's why this course is only open to junior and senior year students as they need to have the knowledge from the studio and supporting courses from their first and second years. Considering the details of the required project and the limit of course hours, students are working in groups of two for developing this project.

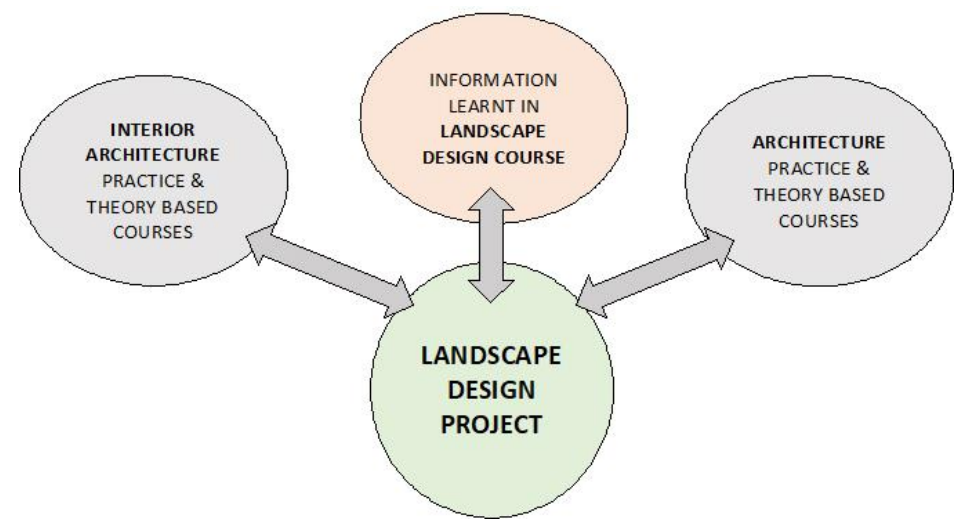

Figure 1. Necessary knowledge to produce the final project (Author's lecture notes).

In addition to the weekly lectures, to develop their landscape design projects, weekly exercises also support the learning process in this course. Each week students are supposed to prepare a one-page presentation showing the progress of their project. In the first week students select their groupmates and project sites either among the given list of possible project site alternatives or they are also welcomed to propose a new project site that they find ecologically problematic in their near living environments. Following the site selection, students start site analysis phase, search for historical, physical, social and cultural characteristics of the site and realize SWOT analysis for each project site. Following this phase, they research about similar projects or design ideas that can be inspirational for them in terms of design development or for creating solutions for ecological problems. Then students start developing their project manifesto and conceptual design diagrams. Week by week students develop their design proposal and for the final submission they prepare a presentation board that brings all ideas and previous works together. During these presentations students are free to use any presentation mediums from computer programs to hand drawings whichever they feel more comfortable and productive (see Picture 3). 


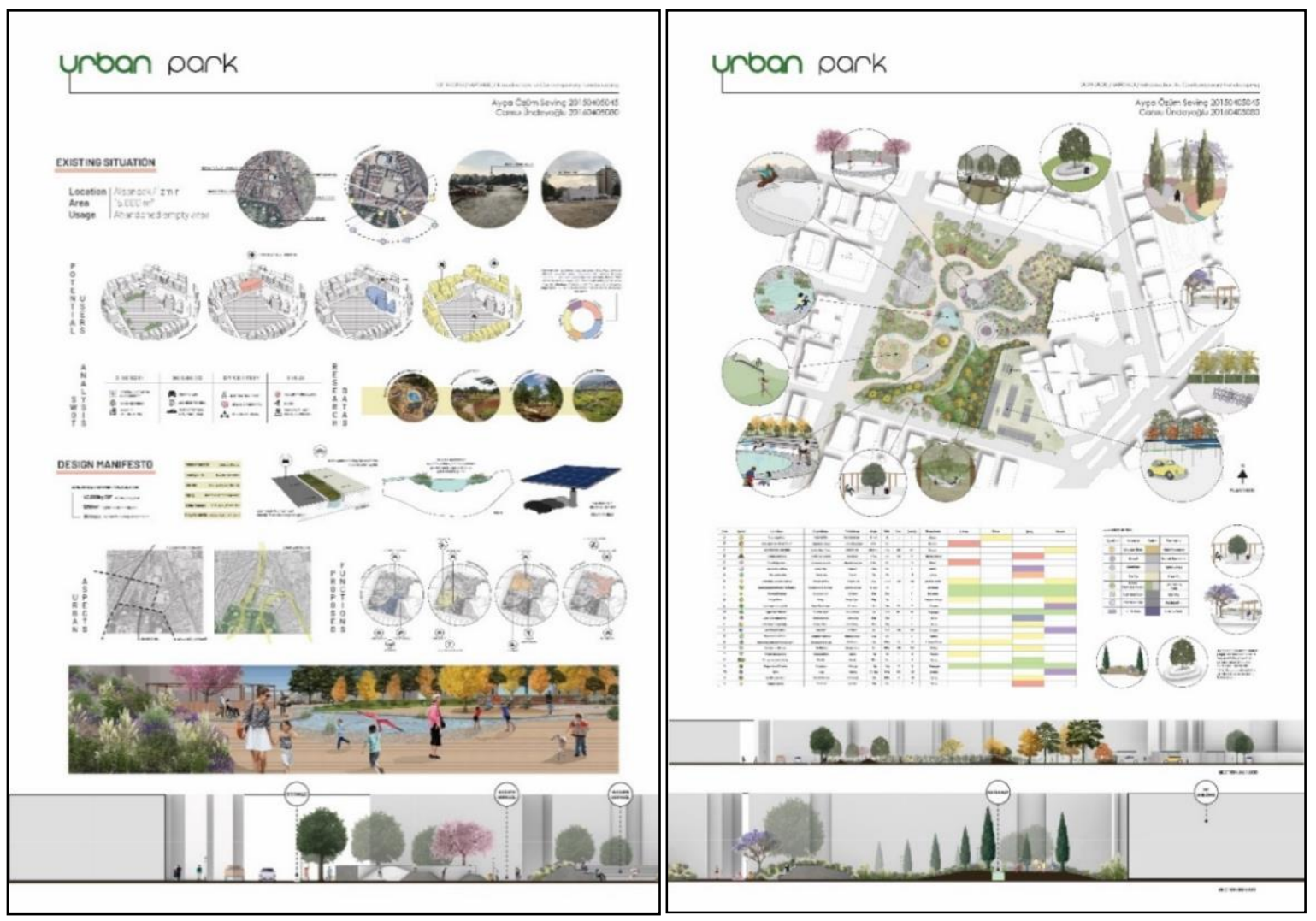

Picture 3. Final presentation board example

One important aspect of this phase is that, each week each group of student stands up in front of all class and present their ideas and all students and instructor give feedbacks. This presentation and feedback sessions help a lot to the progress of students' knowledge and projects. For instance, at the SWOT analysis phase during the first weeks of the course there was a significant difference between the methods used for the analysis among architecture and interior architecture. Interior architecture students were usually weaker in this stage, whereas architecture students come to class with very detailed analysis, problem definitions, and possible propositions (see Picture $4 \& 5$ ). However, at the final presentation, students that were weaker in the beginning showed a great progress and prepared more successful SWOT analysis.

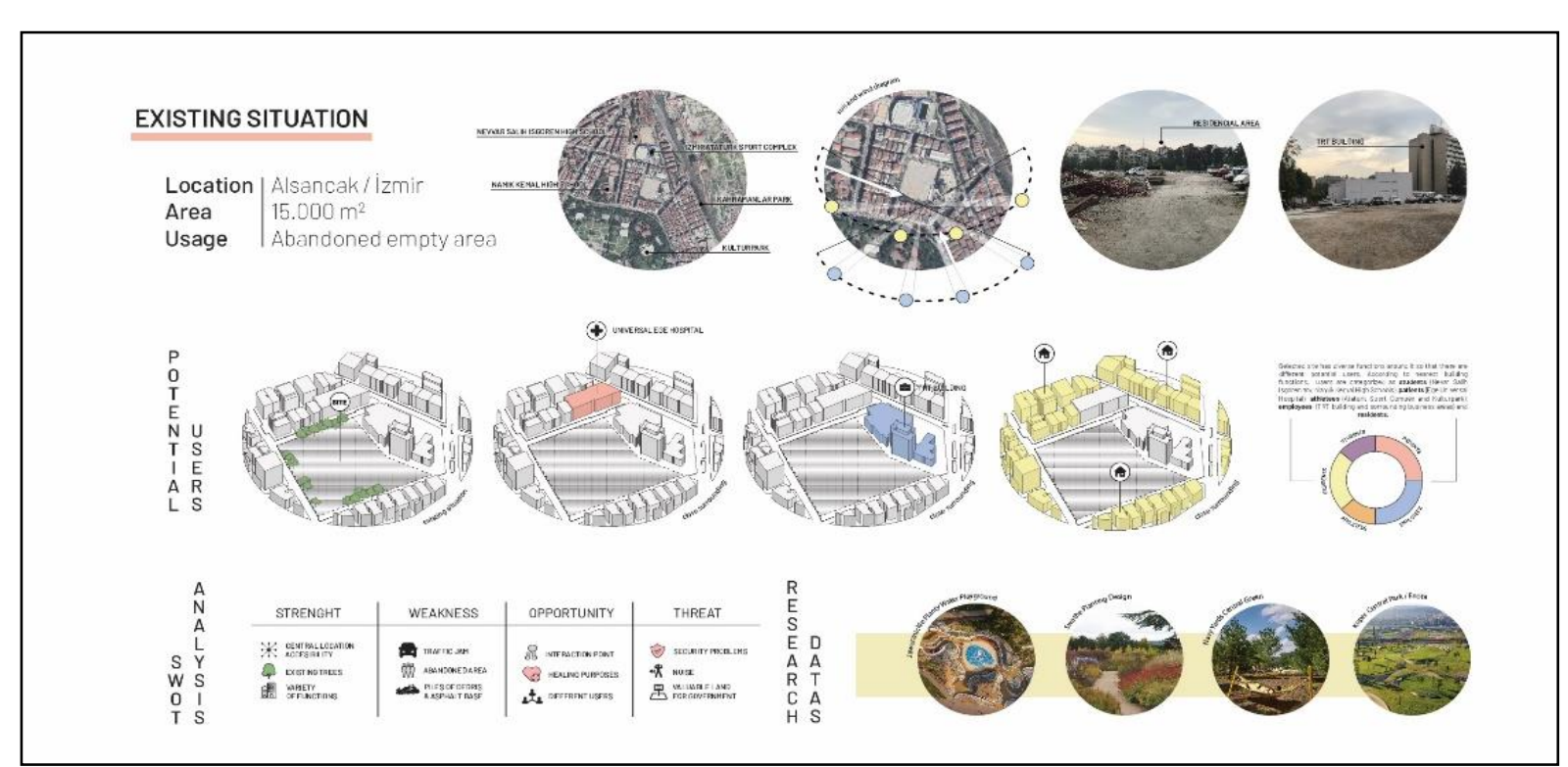

Picture 4. Example of a successful site analysis by ARCH students

Submit Date: 28.01.2020, Acceptance Date: 23.03.2020, DOI NO: 10.7456/11003100/002

Research Article - This article was checked by Turnitin

Copyright $@$ The Turkish Online Journal of Design, Art and Communication 


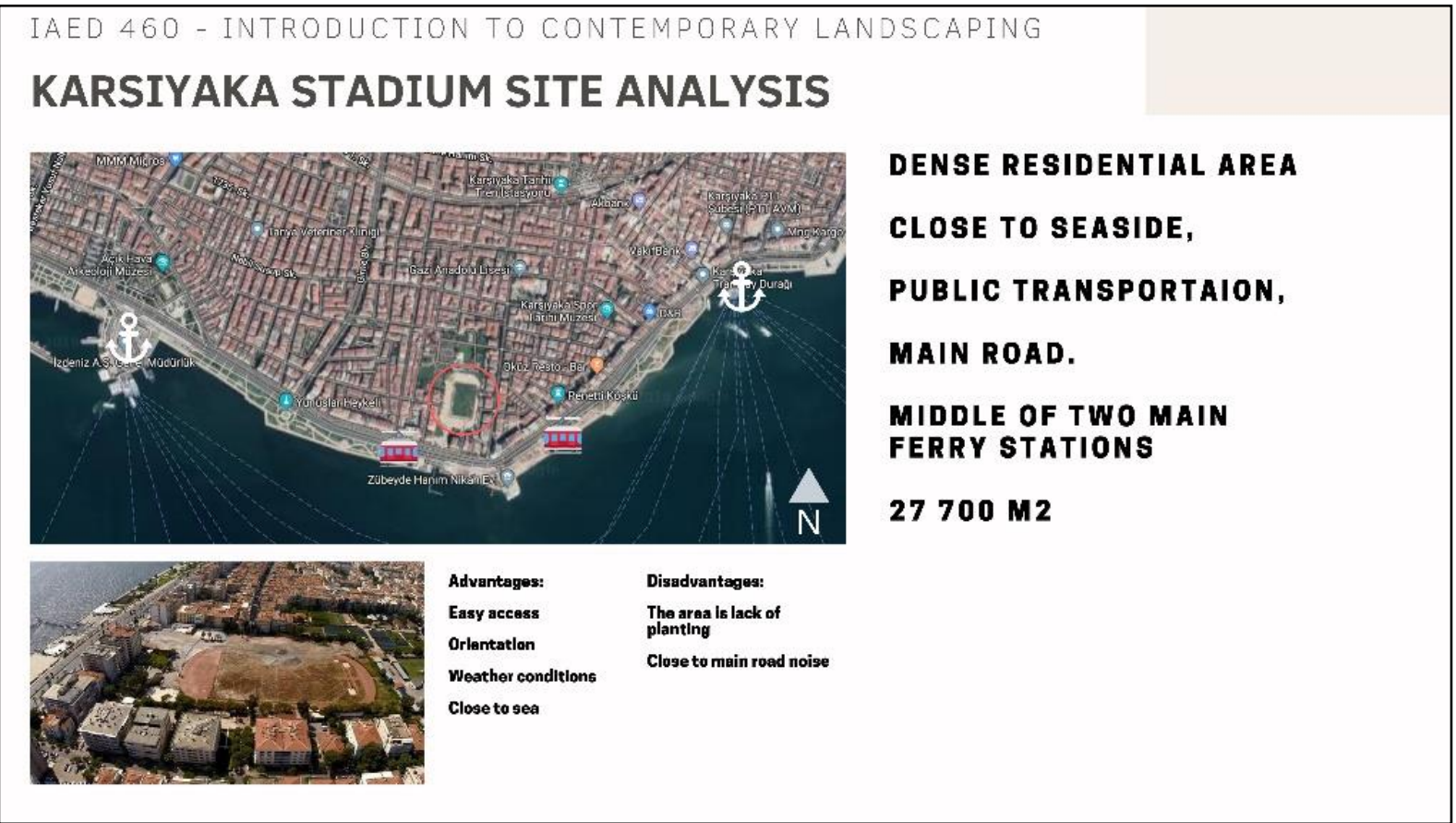

Picture 5. Example of unsuccessful site analysis by IAED students

Additionally, there were also significant differences among students of ARCH and IAED at the representation techniques and presentation of their projects. While IAED students mostly tend to use computer based 3D representation techniques with photorealistic images, ARCH students prefer hand drawings both at project development and final presentation phases. While ARCH students prefer hand sketches or diagrams to develop their design ideas, IAED students preferred to work with computer programs like SketchUp or Lumion to work on different design alternatives and for final presentation (see Picture 6 \& 7).

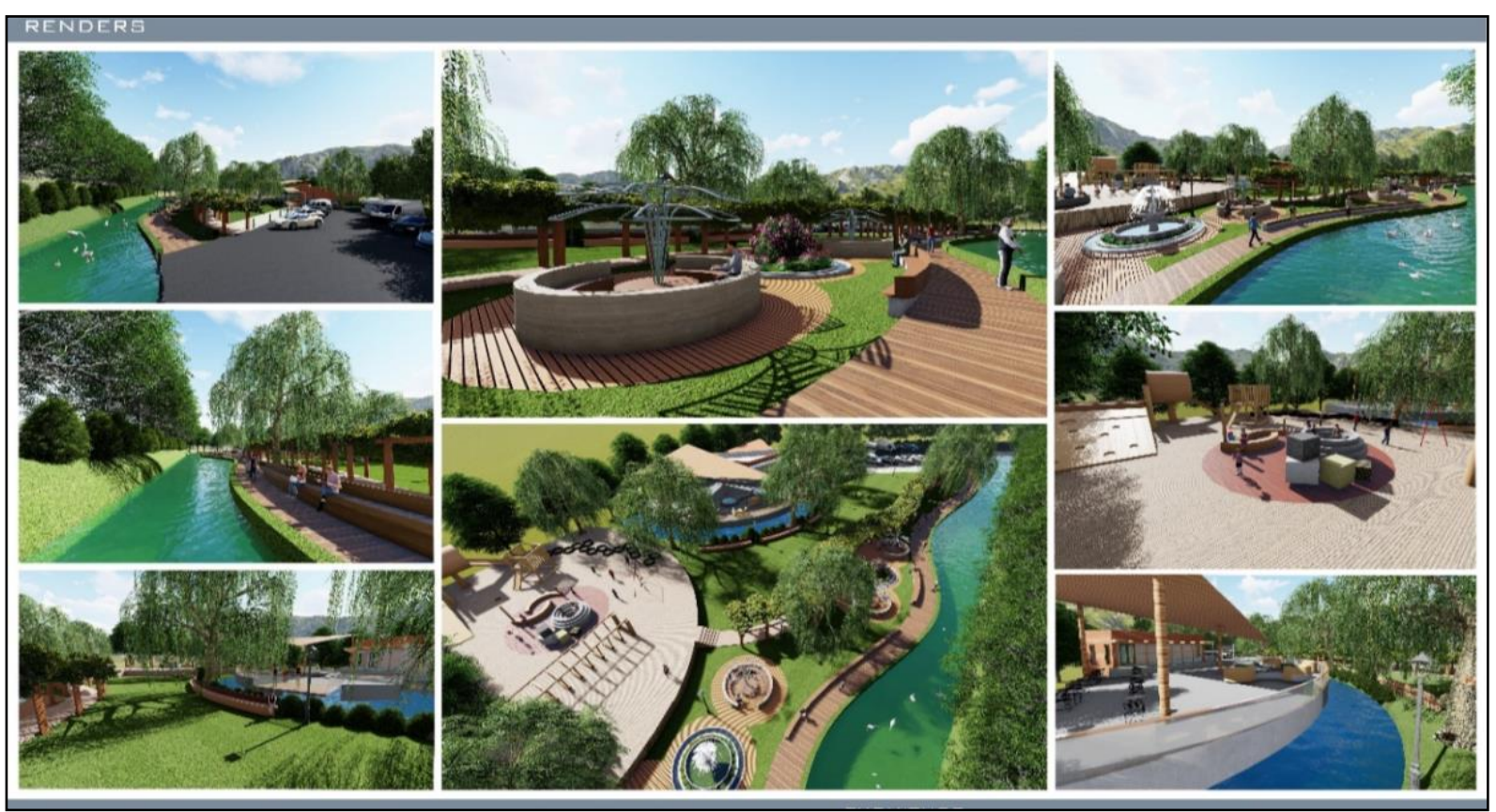

Picture 6. Example of photorealistic computer based presentation by IAED students 


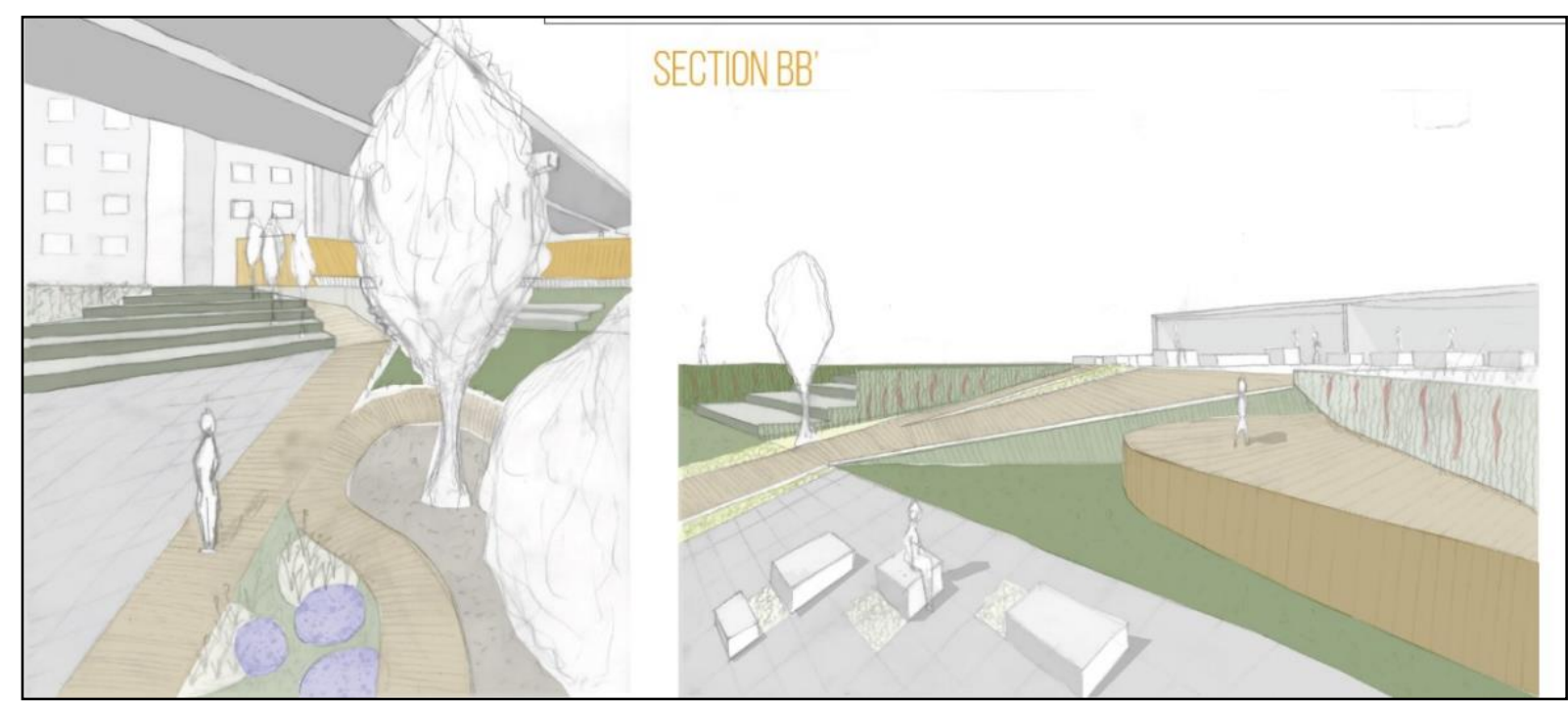

Picture 7. Example of a hand drawing based presentation by ARCH students

\section{CONCLUSION}

Before discussing the outcomes of this course and how students benefit from, it should be highlighted that there are several limitations for this study. First of all, to discuss the outcomes of multidisciplinary design education through only one course that is run with students from only two departments may not be sufficient. To get more comprehensive results, other courses with multidisciplinary structure and include students from various different design disciplines should also be investigated. Secondly, in the intense curriculum of ARCH and IAED departments where students take studio courses 8 hours a week and develop a design project in such a duration, this course where they need to develop a fully designed project only in 3 hours a week, is a quite heavy workload on the students. Since this is an elective course and usually students expect less intensity in the elective courses, requirements of the course are explained in the first week to let them know this heavy workload and they are warned to take this course only if they have interest in landscape design and willing to realize the requirements. This time concern and the students' vision regarding an elective course may also affect some of the outcomes of the projects. Thus heavy workload and the structure of the course reveals the necessity of successful and hardworking students in this course. The theoretical background of the course which requires problem definition and critical thinking for problem solving and project development is difficult to implement at lower years. As Soliman (2017) also state the problem-seeking phase is only applicable to advanced design studios and especially students of such a heavy course should be willing to seek and observe reallife problems.

Outcomes of this study is based on the seven years of experience in this course that is grounded on the analysis of the progress of seven different student groups through their grades, my observations as an instructor and a landscape architect on the improvement of the students' design skills, and informal talks with students' regarding the course structure and indicates how students benefited from the course and their design abilities developed. This study significantly revealed three main outcomes.

First of all, both students' progress in terms of the quality of their design and design expression methods and their grades in between the first weeks and last weeks of the course exposed that inclusion of students from different disciplines in the same course increases the success rate of students in problem solving with the help of cross-learning experiences. During different phases of the project students experience various methods and tools that students from another discipline uses and this experience help them to overcome their design problems. Students from each discipline gains an appreciation of the other disciplines and the diversity provided by students of other departments. In this course, collaboration occurs both during group works, where students mostly prefer to work with their friends from the same department, and also during the weekly project presentations where students have the chance to get feedbacks from other students and they can see what others are doing. During these feedback sessions, students present their inspiration sources, the plants and hard surface material 
selections along with their problem definitions, project manifestos for solving ecological problems of the site and also the technical drawings and renders. At these stages students get inspirations from the presentations of other students, sometimes they start to use similar techniques or materials or from the critique to one group the other groups found chance to correct their mistakes. These kind of differences and being able to see each other's' strengths and weaknesses really helps students to self-criticize and improve their skills. By obtaining and integrating information from different disciplines, the projects that are proposed in this course becomes more successful in terms of constructability and usability of the project.

Secondly, experiences with seven different student groups and their comments on the course support the idea that during design education, having the chance of participation to courses from different disciplines helps students to broaden their perspectives on problem solving during design phase. Close ties in between three main design disciplines, architecture, interior architecture and landscape architecture and the fluidity of boundaries in between these three disciplines help students to realize that focusing only in interior design of a building or to the construction of a structure cannot provide successful results without a comprehensive understanding of the whole site. Of course specialization is still necessary, however, a basic knowledge about disciplines that are neighboring to students' main design disciplines would broaden their design perspective and ability to solve design problems. This does not mean that an architecture or interior architecture student can design a landscape project on their own after taking this course, however, they will have the initial knowledge on the basic principles of landscape architecture.

Finally, a course that incorporates technical knowledge on a design field with actual projects in environments that students experience in their everyday life increase their interest in project. During the course students are given project sites that are pre-decided by the course instructor which include a terrace garden from the faculty building, an open space from the university campus, two parks from the neighborhood that the university is located, several significant and well known sites from the city İzmir - a shopping street, a roof top of an art gallery, an old stadium area, a waterfront park etc. - In addition to these sites some student groups brought their own suggestions such as a non-used lot from the city center, a non-used area under a major highway bridge, a park which has no users and so on. All of these sites are both ecologically and socially problematic and also spaces that these students experience during their daily lives. This experience increases students' interest to the sites. At the beginning of the projects the problems and potentials of the sites were discussed and students who brought their own suggestions were observed to be more excited to solve these problems and they started to imagine how they would use these areas if they were well designed. The final results of the projects and student grades also revealed that students who worked on their own suggestion sites from their daily environments got higher grades compared to the students who selected a project site from the pre-decided sites.

Results of this course, that is based on the analysis of interest levels and grade progress of different student groups during seven years, indicate that working with realistic design problems and with sites that students are well aware of, influences and improves the learning process in a design project. When students dealing with design problems that they know closely lead to very creative results in projects. As Smith and Tillman (2004) and Ng (2013) suggest this approach highlights the importance of hands on learning in design courses and working on site also provides students with the opportunity to apply learning processes to real-life context (Ng, 2013; Smith and Tillman, 2004).

To sum up, giving a chance to collaborate with students from other disciplines, also focusing on topics that are not well acquired during their own departmental courses and to see their own strengths and weaknesses while working on a project from an everyday site and following the process of other students' projects is a great learning experience that can prepare students from design related fields to their professional lives where they will have to work in multidisciplinary design teams. 


\section{ACKNOWLEDGEMENTS}

I would like to thank lecturer Thomas Keogh for building the initial structure of this course together with me and sharing his knowledge on the history of gardening with students of the course. I also would like to thank Dr. Hande Atmaca Çetin for sharing her experiences and being a guest critique to the course. Above all, I thank all my students for showing a great interest and performance during the course and for making this course a great experience for me.

\section{REFERENCES}

Barnes-Powell, T. (2008). Can we meet the challenges of the 21st century holding on to the educational ideologies of the 19th century. In CLTAD conference, 3 - 4 April 2008, New York, USA.

Bender, D. M. (2005). Developing a collaborative multidisciplinary online design course. The Journal of Educators Online, 2(2), 1-12.

Blossom, N., Matthews, D. and Gibson, K. (2002). Linking interior design education and practice. Perspective, 26(1), 24-29.

Canniffe, B. J. (2011). Designing in and for communities: breaking institutional bariers and engaging design students in meaningful and relevant projects. Iridescent, 1(1), 202-215.

Davis, M. (2011). Relevance in a complex world. icograda design education manifesto', in AG Bennett \& O Vulpinari (eds), ICOGRADA design education manifesto. International Council of Graphic Design Associations, Tapei, 72-75.

Dubberly, H. (2011). Input for updating the icograda design education manifesto. In A. G. Bennett \& O. Vulpinari (Eds.), ICOGRADA design education manifesto. International Council of Graphic Design Associations, Tapei, 76-81.

Erkan, Ö. (2013). Interdisciplinary collaboration between interior architecture and industrial product design programs in turkey. Procedia-Social and Behavioral Sciences, 106, 1540-1547.

Fleischmann, K. (2013) Integrating multidisciplinary collaboration in undergraduate design education: too many cooks spoil the broth? In Proceedings from the 2nd International Conference for Design Education Researchers (3) pp. 1212-1230. From: 2nd International Conference for Design Education Researchers, 14-17 May 2013, Oslo, Norway.

Friedman, K. (2001) Design education in the university: Professional studies for the knowledge economy. In C. Swann \& E.Young (Eds.), (2002) Re-inventing design education in the university, Proceedings of the Perth International Conference. Perth: School of Design, Curtin University of Technology, 14-28

Haukka, S. (2010). From education to work in australia's digital content industries: the opinions and practices of aspiring creatives in the creative industries. 60Sox Report.

Hunt, J. (2011). Icograda design education manifesto. In AG Bennett \& O Vulpinari (eds). ICOGRADA design education manifesto. International Council of Graphic Design Associations, Tapei, 86-89.

Icograda (2011). "ICOGRADA Design Education Manifesto", Tapei.

Kimmons, J. V. and Spruiell, P. R. (2005). Using problem-based learning in a multidisciplinary setting. Clothing and Textiles Research Journal, 23(4), 385-395.

Masters, C. and Baker, V. O. T. and Jodon, H. (2013). Multidisciplinary, team-based learning: The simulated interdisciplinary to multidisciplinary progressive-level education (simple $\odot$ ) approach. Clinical Simulation in Nursing, 9(5), e171-e178.

Pektaş, Ş. T. (2007). A structured analysis of caad education. Open House International, 32(2), 46-54. Sebastian, R. (2010). Integrated design and engineering using building information modelling: A pilot project of small-scale housing development in the netherlands. Architectural Engineering and Design Management, 6(2), 103-110.

Smith, L. P. and Tillman, R. J. (2004). Instructional design (3rd ed.). New York: Wiley.

Soliman, A. M. (2017). Appropriate teaching and learning strategies for the architectural design process in pedagogic design studios. Frontiers of Architectural Research, 6(2), 204-217.

Szenasy, S. (2004). School survey 2004 - do america's design schools encourage interdisciplinary collaboration?. Metropolis, August/September, 88-91.

$\mathrm{Ng}$, V. (2013). Values of learning through'place-making'in the design studio. ArchNet-IJAR: International Journal of Architectural Research, 7(1), 86.

Whyte, J. and Bessant, J. (2007). Making the Most Of UK Design Excellence: Equipping UK Designers To Succeed in the Global Economy. Tanaka Business School Report. 
Yurtsever, B. and Çakir, G. (2012). An assessment for interdisciplinary education modal implementation of basic design education in architecture. Procedia-Social and Behavioral Sciences, 51, 157-161.

\section{ELECTRONIC SOURCES}

Design Victoria, (2009). Designing our future: A report on tertiary design education in Victoria. Retrieved from https://www.ico-d.org/database/files/library/DesigningOurFuture.pdf Accessed: 15.12.2019

IIDA Report, (1998). International interior design association. Retrieved from http://www.iida.org/ files/pdf_found_education_analysis.pdf Accessed: 20.12.2019.

Pegasus Communications, (2012). What is systems thinking?, Retrieved from http://www.pegasuscom.com/systems-thinking.html Accessed: 24.12.2019. 